\title{
Overlapping profiles of $A \beta$ peptides in the Alzheimer's disease and pathological aging brains
}

\author{
Brenda D Moore ${ }^{1}$, Paramita Chakrabarty', Yona Levites', Tom L Kukar², Ann-Marie Baine³, Tina Moroni³ \\ Thomas B Ladd', Pritam Das ${ }^{3}$, Dennis W Dickson ${ }^{3}$ and Todd E Golde ${ }^{1 *}$
}

\begin{abstract}
Introduction: A hallmark of Alzheimer's disease (AD) is the presence of senile plaques composed of aggregated amyloid $\beta(A \beta)$ peptides. Pathological aging (PA) is a postmortem classification that has been used to describe brains with plaque pathology similar in extent to $A D$, minimal cortical tau pathology, and no accompanying history of cognitive decline in the brain donor prior to death. PA may represent either a prodromal phase of $A D$, a benign form of $A \beta$ accumulation, or inherent individual resistance to the toxic effects of $A \beta$ accumulation. To attempt to distinguish between these possibilities we have systematically characterized $A \beta$ peptides in a postmortem series of PA, AD and non-demented control (NDC) brains.
\end{abstract}

Methods: $A \beta$ was sequentially extracted with tris buffered saline (TBS), radioimmunoprecipitation buffer (RIPA), $2 \%$ sodium dodecyl sulfate (SDS) and 70\% formic acid (FA) from the pre-frontal cortex of 16 AD, eight PA, and six NDC patients. These extracts were analyzed by 1) a panel of A 3 sandwich ELISAs, 2) immunoprecipitation followed by mass spectrometry (IP/MS) and 3) western blotting. These studies enabled us to asses $A \beta$ levels and solubility, peptide profiles and oligomeric assemblies.

Results: In almost all extracts (TBS, RIPA, 2\% SDS and 70\% FA) the average levels of A $\beta 1-40, A \beta 1-42$, A $\beta$ total, and $A \beta x-42$ were greatest in $A D$. On average, levels were slightly lower in PA, and there was extensive overlap between $A \beta$ levels in individual PA and AD cases. The profiles of A $\beta$ peptides detected using IP/MS techniques also showed extensive similarity between the PA and AD brain extracts. In select AD brain extracts, we detected more aminoterminally truncated $A \beta$ peptides compared to PA patients, but these peptides represented a minor portion of the $A \beta$ observed. No consistent differences in the $A \beta$ assemblies were observed by western blotting in the PA and $A D$ groups.

Conclusions: We found extensive overlap with only subtle quantitative differences between A $\beta$ levels, peptide profiles, solubility, and SDS-stable oligomeric assemblies in the PA and AD brains. These cross-sectional data indicate that $A \beta$ accumulation in PA and AD is remarkably similar. Such data would be consistent with PA representing a prodromal stage of $A D$ or a resistance to the toxic effects of $A \beta$.

\section{Introduction}

Alzheimer's disease (AD) is characterized by large numbers of extracellular amyloid plaques with dense amyloid cores that are associated with dystrophic neurites and neuroinflammatory changes as well as intraneuronal neurofibrillary tangles. Pathological aging (PA) patients also have abundant and widespread amyloid plaques;

\footnotetext{
* Correspondence: tgolde@ufl.edu

'Center for Translational Research in Neurodegenerative Disease, Department of Neuroscience, McKnight Brain Institute, College of Medicine, University of Florida, 1275 Center Drive, Gainesville, FL, 32610, USA Full list of author information is available at the end of the article
}

however, these plaques have typically been described as diffuse in nature. In PA there are fewer cored plaques and there is little or no inflammatory reaction, neuritic pathology or neurofibrillary tangles in the cortex. These patients are reported to be cognitively normal prior to death [1-3]. Based on our current understanding of the progression of $\mathrm{AD}, \mathrm{PA}$ may represent a prodromal phase of $\mathrm{AD}$ (for example, preclinical stage $1 \mathrm{AD}$, plaque only), a benign form of $A \beta$ accumulation, or inherent individual resistance to the toxic effects of $A \beta$ accumulation $[3,4]$.

\section{Biomed Central}

(c) 2012 Moore et al.; licensee BioMed Central Ltd. This is an open access article distributed under the terms of the Creative Commons Attribution License (http://creativecommons.org/licenses/by/2.0), which permits unrestricted use, distribution, and reproduction in any medium, provided the original work is properly cited. 
$\mathrm{A} \beta$ is the principle component of amyloid deposits in the $\mathrm{AD}$ brain. It is a secreted peptide produced through sequential cleavage of the Amyloid- $\beta$ Protein Precursor (APP) by $\beta$ - and $\gamma$-secretases [5-7]. A $\beta$ peptides have a heterogeneous carboxyl-terminus with the majority (approximately $40 \%$ to $70 \%$ ) composed of 40 amino acids $A \beta 1-40$, while a minor product (approximately $5 \%$ to $20 \%)$ contains a two amino acid extension $A \beta 1-42$. Additional minor A $\beta$ peptides are also normally produced (for example, 1-34, 1-37, 1-38 and 1-39), although few reports have quantified the levels of these peptides in the brain [8]. A $\beta 1-42$ is more amyloidogenic and has been implicated as the pathogenic form of $A \beta$ [9]. A recent study also suggested that $A \beta 1-43$ could play a critical role in $A \beta$ accumulation [10]. Furthermore, a variety of truncated and modified $A \beta$ peptides have been described (for example, 1-28, 1-29, 1-45, 2-46, 3$44,3-47,2-42,4-42,5-42,6-42,7-45,8-42,1-$ 42Met35ox, pE3-42, pE11-42) [11-18]. Of these truncated and modified forms the pyroglutamate modified forms, $A \beta p E 3-42$ and $A \beta p E 11-42$, have been highly investigated, as key species possibly involved in initial nucleation or seeding events [19-22].

Once liberated from APP, A $\beta$ can self-associate to form various aggregates. These aggregates include soluble oligomers, protofibrils, and amyloid fibrils [23,24]. Although there is currently debate within the field regarding which form or forms of $A \beta$ aggregates are the most pathogenic, there is general consensus that the aggregated forms of $A \beta$ are harmful and that $A \beta 1-42$ or possibly $A \beta 1-43$ is required for aggregation in the absence of internal mutations within $A \beta$ [25-30].

Because many different forms of $A \beta$ exist and accumulate in various higher order assemblies, it is possible that the relatively poor correlation between cognitive deficits and plaque load is attributable to either qualitative or quantitative differences between a particular species or assembly of $A \beta$. This poor correlation could also reflect an inherent difference in vulnerability to 'toxic' effects of different forms of $A \beta$ aggregates. Additionally, given the growing acceptance of the concept of preclinical AD [4,31,32], where the initial stage is defined by the presence of $A \beta$ deposits in the absence of other pathologies and no evidence for cognitive impairment, the poor correlation could be attributable to differences in time from initial deposition to frank neurodegeneration and clinical deterioration.

As PA represents the most clear cut example of the dissociation between $A \beta$ accumulation and cognitive impairment, investigation of the type and species of $A \beta$ peptides in PA cohorts could provide novel insights into the poor correlation between $A \beta$ and cognition. Previous studies investigating differences in $A \beta 1-40$ and A $\beta 1-42$ species extracted from PA and AD brains demonstrated that $A \beta 1-40$ levels were as much as approximately 20-fold higher in AD brains compared to PA brains whereas A $\beta 1-42$ levels were only about 2-fold higher [33]. A more recent and extensive study using both ELISAs and western blotting to analyze A $\beta$ levels and oligomeric assemblies failed to detect major differences in PA and AD [34]. Other more anecdotal studies comparing oligomeric assemblies in a single PA brain versus $A D$ brains failed to detect significantly elevated levels of $A \beta$ dimer in the PA brain extracts compared to AD brain extracts [35].

Although these studies suggest that there may be both quantitative and qualitative differences in $A \beta$ peptides in PA brains as opposed to AD brains, we felt that a more extensive investigation with larger cohorts was warranted. Here we report on our analysis of $A \beta$ peptides sequentially extracted from the pre-frontal cortices of 16 AD patients, eight PA patients, and six non-demented controls (NDC) using a battery of biochemical tests. Our analysis shows that AD and PA brains are clearly distinct from controls, but there is extensive overlap between PA and AD with respect to extractable $A \beta$ levels as measured by ELISA. Using immunoprecipitation mass spectrometry (IP/MS) to profile individual $A \beta$ species in the PA and AD brain extracts we find that there is also extensive overlap in the profiles of accumulated $\mathrm{A} \beta$. However, individual $\mathrm{AD}$ brains showed more extensive heterogeneity with an increase of diversity of A $\beta$ species, particularly amino-terminally truncated $A \beta$ species. Assessment of SDS-stable oligomers by western blotting also showed no consistent differences between PA and NDC.

\section{Materials and methods}

\section{Selection of PA cases}

Frozen pre-frontal cortex $(\mathrm{AD}=16, \mathrm{PA}=8, \mathrm{NDC}=7)$ was obtained from the Mayo Clinic Brain Bank with informed consent, in accordance with the Mayo Clinic institutional review board, using previously described acquisition and diagnostic analyses [2,36,37]. We analyzed 16 brains from AD patients (age range = 66 to 99; average age $=82$ ), eight pathologic aging brains from subjects (age range $=66$ to 90 ; average age $=80$ ) without clinical evidence of dementia and seven brains with rare or no $\mathrm{AD}$ lesions from elderly individuals without clinical evidence of a neurological illness (age range = 66 to 87 ; average age $=76$ ). Table 1 summarizes the cases studied here.

\section{Brain extraction}

Frozen pre-frontal cortex tissue was cryo-pulverized in liquid nitrogen. Briefly, for ELISA and IP/MS, the cryopulverized tissue was sequentially extracted with Trisbuffered saline (TBS), radioimmunoprecipitation buffer 
Table 1 Summary of demographics of human subjects studied.

\begin{tabular}{|c|c|c|c|}
\hline & & Group & \\
\hline & $A D(n=16)$ & $\mathrm{PA}(\mathrm{n}=8)$ & NDC $(n=7)$ \\
\hline Age & 82 (66 to 99) & 80 (66 to 90$)$ & 76 (66 to 87$)$ \\
\hline \multicolumn{4}{|l|}{ Gender } \\
\hline M & $8(50 \%)$ & $6(75 \%)$ & $5(71 \%)$ \\
\hline F & $8(50 \%)$ & $2(25 \%)$ & $2(29 \%)$ \\
\hline \multicolumn{4}{|l|}{ Braak } \\
\hline 2.0 & $0(0 \%)$ & $4(50 \%)$ & $4(57 \%)$ \\
\hline 2.5 & $0(0 \%)$ & $1(13 \%)$ & $1(14 \%)$ \\
\hline 3.0 & $0(0 \%)$ & $3(38 \%)$ & $2(29 \%)$ \\
\hline 3.5 & $0(0 \%)$ & $0(0 \%)$ & $0(0 \%)$ \\
\hline 4.0 & $2(13 \%)$ & $0(0 \%)$ & $0(0 \%)$ \\
\hline 4.5 & $2(13 \%)$ & $0(0 \%)$ & $0(0 \%)$ \\
\hline 5.0 & $7(44 \%)$ & $0(0 \%)$ & $0(0 \%)$ \\
\hline 5.5 & $2(13 \%)$ & $0(0 \%)$ & $0(0 \%)$ \\
\hline 6.0 & $3(19 \%)$ & $0(0 \%)$ & $0(0 \%)$ \\
\hline \multicolumn{4}{|l|}{ CAA } \\
\hline 0 & $6(38 \%)$ & $5(63 \%)$ & $5(71 \%)$ \\
\hline $0-1+$ & $1(6 \%)$ & $0(0 \%)$ & $1(14 \%)$ \\
\hline $1+$ & $6(38 \%)$ & $0(0 \%)$ & $1(14 \%)$ \\
\hline $1+-2+$ & $1(6 \%)$ & $0(0 \%)$ & $0(0 \%)$ \\
\hline $2+$ & $1(6 \%)$ & $1(13 \%)$ & $0(0 \%)$ \\
\hline $2+-3+$ & $0(0 \%)$ & $1(13 \%)$ & $0(0 \%)$ \\
\hline $3+$ & $0(0 \%)$ & $1(13 \%)$ & $0(0 \%)$ \\
\hline $4+$ & $1(6 \%)$ & $0(0 \%)$ & $0(0 \%)$ \\
\hline
\end{tabular}

Median ages (age range), gender distribution, Braak score and CAA score are denoted. CAA scoring was done by post-mortem neuropathologic analysis by $D W$. AD, Alzheimers disease; CAA, cerebral amyloid angiography; $F$, female; $M$, male; $n$, number; NDC, non-demented controls; PA, Pathological aging.

(RIPA), $2 \%$ sodium dodecyl sulfate (SDS) and $70 \%$ formic acid (FA) containing protease inhibitor cocktail (Roche, Indianapolis, IN, USA) as described before at a concentration of $300 \mathrm{mg} / \mathrm{mL}$ [38]. For immunoblotting, samples were either serially extracted in TBS and $2 \%$ SDS or directly extracted with RIPA at a concentration of $500 \mathrm{mg} / \mathrm{mL}$.

\section{ELISA}

TBS, RIPA, 2\% SDS and neutralized 70\% FA extracted samples were diluted appropriately and used for sandwich ELISAs as described previously [39]. A $\beta 1-40$ was captured with monoclonal antibody (mAb) Ab9 (human Aß1-16 specific; T.E. Golde) and detected by horseradish peroxidase (HRP)-conjugated $\mathrm{mAb}$ 13.1.1 (human A $335-40$ specific; T.E. Golde); A $\beta 1-42$ was captured with mAb 2.1.3 (human A $335-42$ specific; T.E. Golde) and detected by HRP-conjugated mAb Ab9; Total A $\beta$ was captured with mAb Ab9 and detected by HRP-conjugated mAb 4G8 (Covance, Princeton, NJ, USA); A $\beta x-$ 42 was captured with mAb 2.1.3 and detected by HRPconjugated mAb 4G8.
Immunoprecipitation followed by mass spectrometry (IP/ MS)

Magnetic sheep-anti-mouse IgG beads (Invitrogen, Grand Island, NY, USA) were incubated with $4.5 \mu \mathrm{g}$ antibody (either Ab9 or 4G8 (Covance)) for 30 minutes at room temperature with constant shaking. The beads were then washed and incubated with each extract, which were diluted appropriately. All sample incubations were in the presence of $0.1 \%$ TritonX-100 (Tx-100) and either 10 pmol A $\beta 1-28$ (TBS and RIPA extracts) or $100 \mathrm{pmol} \mathrm{A} \beta 1-28$ (2\% SDS and 70\% FA extracts) as an internal calibration standard. The samples were successively exposed to Ab9 and 4G8 coated beads for 30 minutes each with rotation. Bound beads were washed sequentially with $0.1 \%$ and $0.05 \% \mathrm{Tx}-100$ followed by water. Samples were eluted using a mix of $75 \%$ acetonitrile, $24.9 \%$ water and $0.1 \%$ FA. Samples were mixed in equal volume with sinapinic acid (25 $\mathrm{mg} / \mathrm{mL}$ ) in $50 \%$ acetonitrile, $49.5 \%$ water and $0.5 \%$ trifluoroacetic acid, and $1 \mu \mathrm{L}$ was spotted onto a ProteinChip Gold Array (A-H format) (Bio-Rad Hercules, CA, USA) and analyzed with a Bio-Rad ProteinChip System Series 4000 (Enterprise Edition) mass spectrometer.

\section{Western blotting}

TBS, RIPA and $2 \%$ SDS brain lysates, heated at $50^{\circ} \mathrm{C}$ for three minutes in the presence of denaturing sample buffer, were separated on $4 \%$ to $12 \%$ Bis-Tris gel (Bio-Rad) in $1 \times 2$-(N-morpholino)ethanesulfonic acid (MES) running buffer (Bio-Rad). Initially, we performed a comparative analysis of different immunoblotting techniques with different combinations of membranes $(0.2 \mu \mathrm{m}$ nitrocellulose and $0.2 \mu \mathrm{m}$ polyvinylidene fluoride (PVDF)) and antigen retrieval techniques (boiling, glutaraldehyde and guanidine) in combination with three different primary antibodies (4G8, 82E1 (IBL, Hamburg, Germany) and Ab5 (human A $\beta 1-16$ specific; T.E. Golde). After extensive analysis samples immunoblotted with $82 \mathrm{E} 1$ on boiled nitrocellulose membranes yielded the best results in terms of sensitivity and resolution. Transferred membranes were blocked in Starting Block (Thermo Scientific, Waltham, MA) and incubated overnight with primary antibody (82E1) and detected with donkey anti-mouse antibody conjugated to HRP (Jackson ImmunoResearch, West Grove, PA). Chemilumiscence signal (West Femto Chemiluminescent Substrate (Thermo Scientific)) was visualized with a FujiFilm system.

\section{Statistical analysis}

Results, unless otherwise mentioned, were analyzed with Prism 5 (GraphPad) by one way analysis of variance (ANOVA) with tukey post hoc test and presented as 
data \pm standard error of the mean (s.e.m.). Statistical significance is denoted by an asterisk.

\section{Results}

Immunohistochemical characterization of $A \beta$ plaques and phospho-tau in AD, PA and NDC

The sample population was chosen based on long standing $\mathrm{AD}$ and PA classification systems. Brains selected as PA had no evidence of cognitive decline in the clinic, but had extensive cortical $\mathrm{A} \beta$ plaques (Table 1). To obtain more extensive characterization of $\mathrm{A} \beta$ and tau pathology in the PA cohort, we immunostained frontal cortical tissue for total $A \beta$, phospho-tau, $A \beta 1-40$ (13.1.1) and $A \beta 1-42$ (21.3.1) (Figures 1, 2). Consistent with the PA classification system, PA brains had extensive amyloid deposits and displayed only sparse CP13 immunoreactivity whereas AD patients contained widespread amyloid deposits as well as abundant phospho-tau bearing neurofibrillary tangles
(Figure $1 \mathrm{~A}, \mathrm{~B}, \mathrm{C}$ and $1 \mathrm{D}$ and $1 \mathrm{~F}, \mathrm{G}, \mathrm{H}$ and $1 \mathrm{I}$ ). PA brains showed more widespread $A \beta 1-42$ immunoreactivity than A 1 1-40 immunoreactivity, perhaps corresponding to more abundant diffuse plaques as alluded to by independent groups (Figure 2C, D and 2H, I). Cohorts with increased vessel-associated $A \beta 1-40$ immunoreactivity have been subcategorized as having cerebral amyloid angiopathy (CAA); $\mathrm{CAA}+\mathrm{AD}$ patients had more $\mathrm{A} \beta 1-40$ than the corresponding PA group (Figure 2A, B, C, D, F, G, H and 2I).

\section{Biochemical results of $A \beta$ levels in AD, PA and NDC}

We analyzed $A \beta$ levels from sequentially extracted brain lysates using four different anti-A $\beta$ antibody combinations to detect $A \beta 1-40, A \beta 1-42, A \beta$ total and $\mathrm{NH}_{2}$-truncated $A \beta x-42$ species (Figure 3 ). In each of our $A \beta$ ELISAs the detection limit was approximately 0.04 $\mathrm{pmol} / \mathrm{g}$. Compared to the 2\% SDS and 70\% FA extracted fractions, minimal $A \beta$ was detected in the TBS and

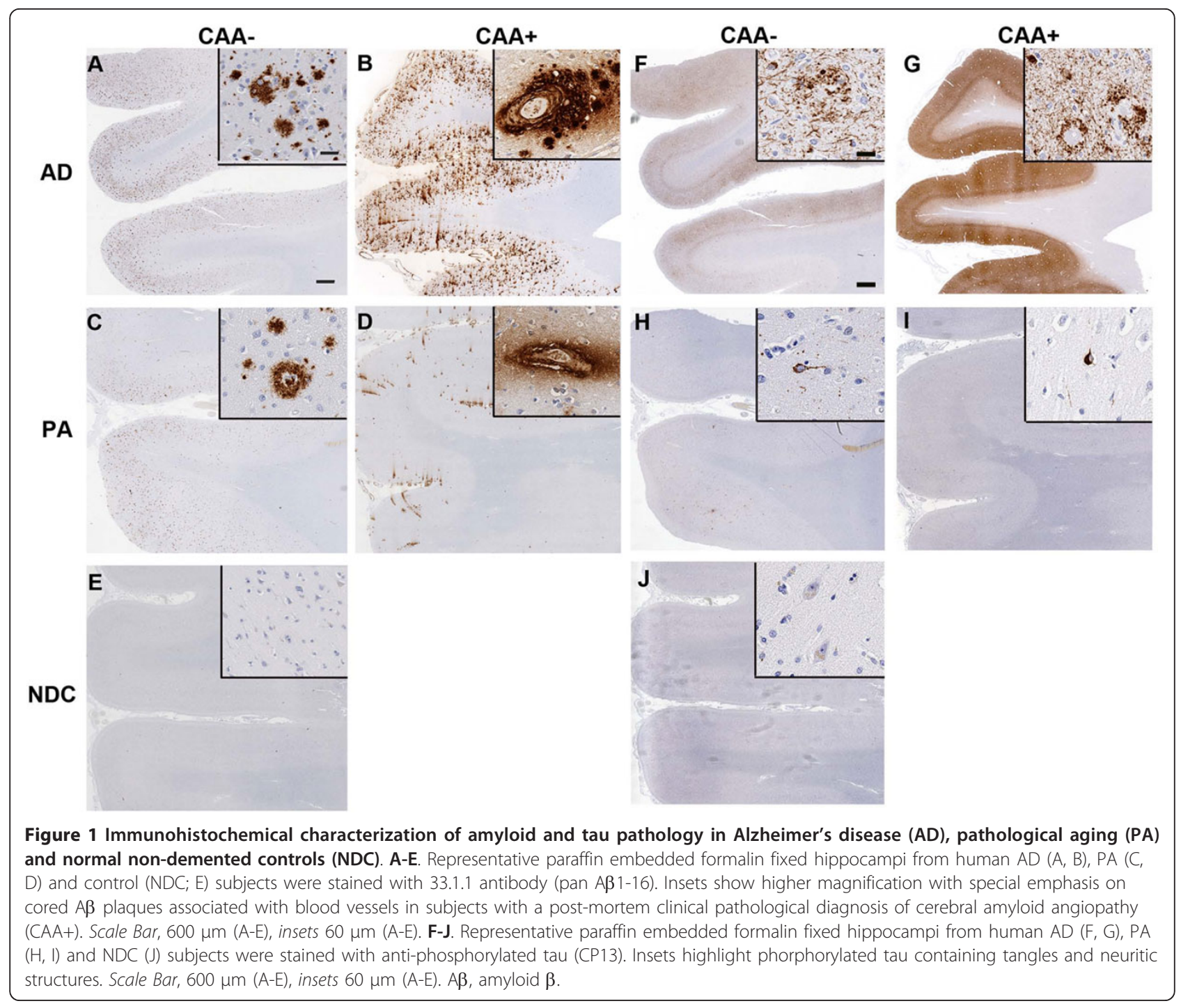




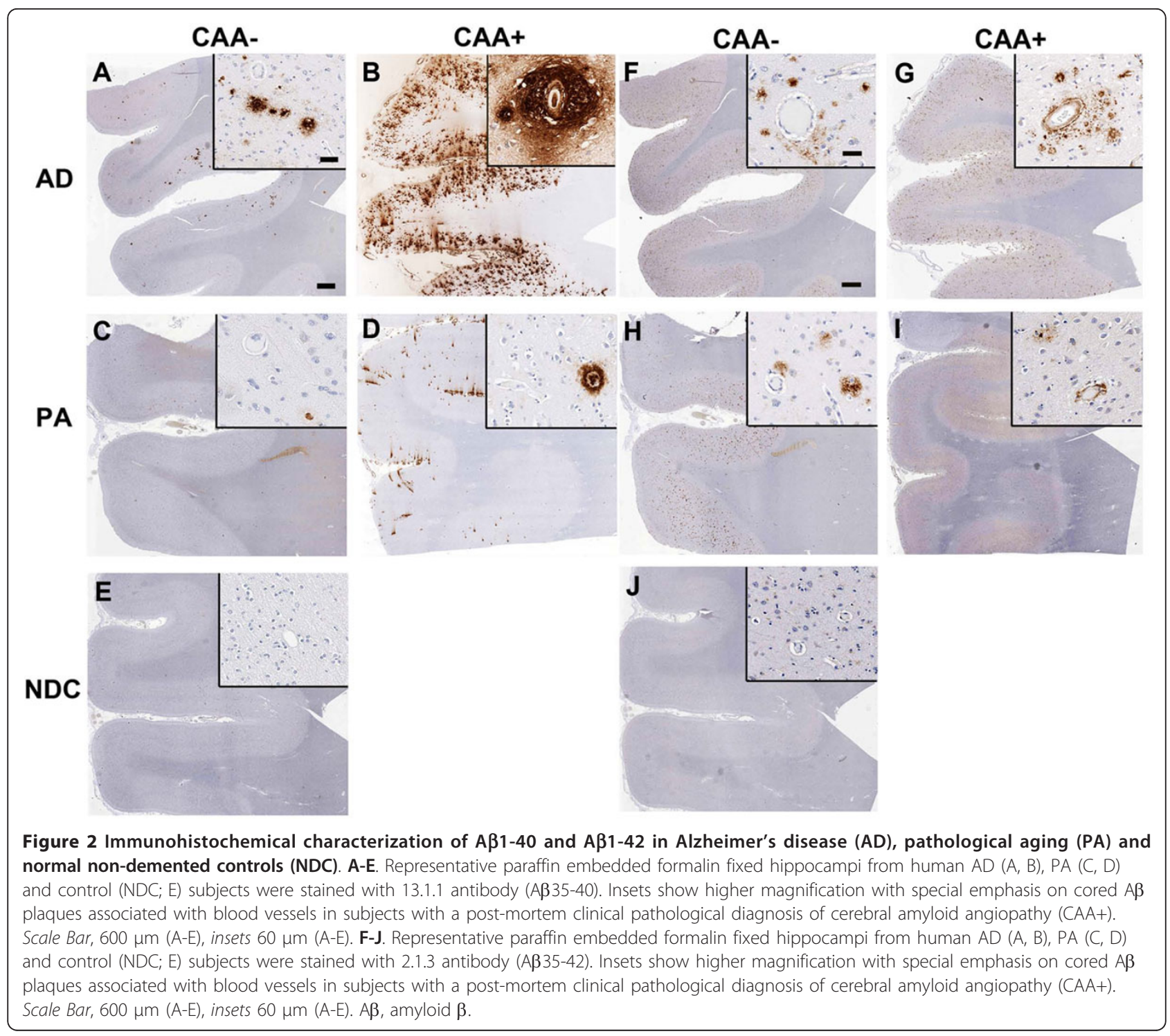

RIPA fractions. For example, in AD extracts the mean total $\mathrm{A} \beta$ measured was $1.0,1.0,184$ and 2,065 $\mathrm{pmol} / \mathrm{g}$ for the TBS, RIPA, 2\% SDS and 70\% FA extracts, respectively (Figure 3 ). The levels of total $A \beta$ in PA lysates were $0.8,0.6,87$ and $1,490 \mathrm{pmol} / \mathrm{g}$ for the TBS, RIPA 2\% SDS and 70\% FA extracts, respectively (Figure $3)$. Thus, the sequential solubility of the $A \beta$ was similar in AD and PA. In NDC brain extracts the levels of total A $\beta$ were $0.2,0.4,7$ and $38 \mathrm{pmol} / \mathrm{g}$ for the TBS, RIPA, $2 \%$ SDS and 70\% FA extracts, respectively (Figure 3 ). Thus, a major difference between AD, PA, and controls, is the dramatic increase in $\mathrm{A} \beta$ that requires either $2 \%$ SDS or $70 \%$ FA to solubilize, suggesting that both AD and PA cohorts had dramatically increased levels of insoluble aggregates of $\mathrm{A} \beta$.

On average, AD and PA lysates exhibited much higher levels of $A \beta$ than NDC samples, with mean $A \beta$ levels in each PA lysate ranging from almost equivalent to approximately $50 \%$ less than the $\mathrm{A} \beta$ level detected in AD lysates (Figure 3). Although not reaching significance in each analysis, there were clear differences between the average levels of $\mathrm{A} \beta$ in $\mathrm{AD}$ and PA extracts as compared to NDC. There was also extensive overlap between individual $\mathrm{A} \beta$ levels in PA and $\mathrm{AD}$ as shown in Additional file 1 Figure S1.

\section{Profiling of $A \beta$ peptides by immunoprecipitation/mass spectrometry (IP/MS)}

We next analyzed the lysates by IP/MS to identify various $A \beta$ peptides associated with $A D, P A$ and NDC cohorts. We used sequential immunoprecipitations using two non-overlapping anti- $\mathrm{A} \beta$ antibodies, $\mathrm{Ab} 9$ (anti-A $\beta 1$-16) followed by $4 \mathrm{G} 8$ (anti-A $\beta 17-24$ ), as our pilot studies suggested that predominant species 

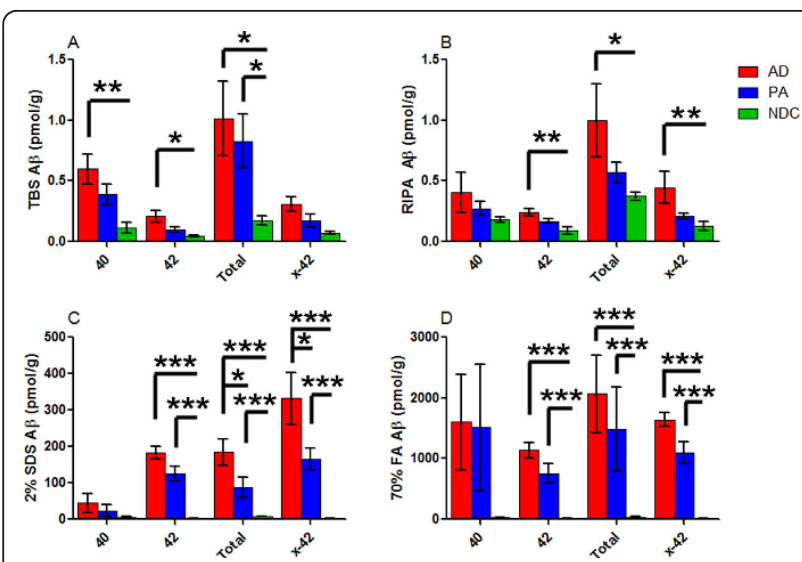

Figure 3 Biochemical analysis of $A \beta$ from human brain lysates Human prefrontal cortical tissue from Alzheimer's disease (AD), pathological aging (PA) and normal controls (NDC) was sequentially extracted with TBS (A), RIPA (B), 2\% SDS (C) and 70\% FA (D). Endspecific sandwich ELISAs measuring $A \beta 1-40, A \beta 1-42$, A $\beta$ total and $A \beta x-42$ are presented for each of these fractions. $N=16(A D), 8$ (PA) and 6 (NDC). $\left({ }^{* *} P<0.001,{ }^{* *} P<0.01,{ }^{*} P<0.05\right.$ by ANOVA with tukey post-hoc analysis raw data analyzed $(\mathbf{A}, \mathbf{B})$ and logtransformed data analyzed (C, D)). A $\beta$, amyloid $\beta$; ANOVA, analysis of variance; ELISA, enzyme-linked immunosorbent assay; FA, formic acid; RIPA, radioimmunoprecipitation buffer; SDS, sodium dodecyl sulfate; TBS, Tris buffered saline.
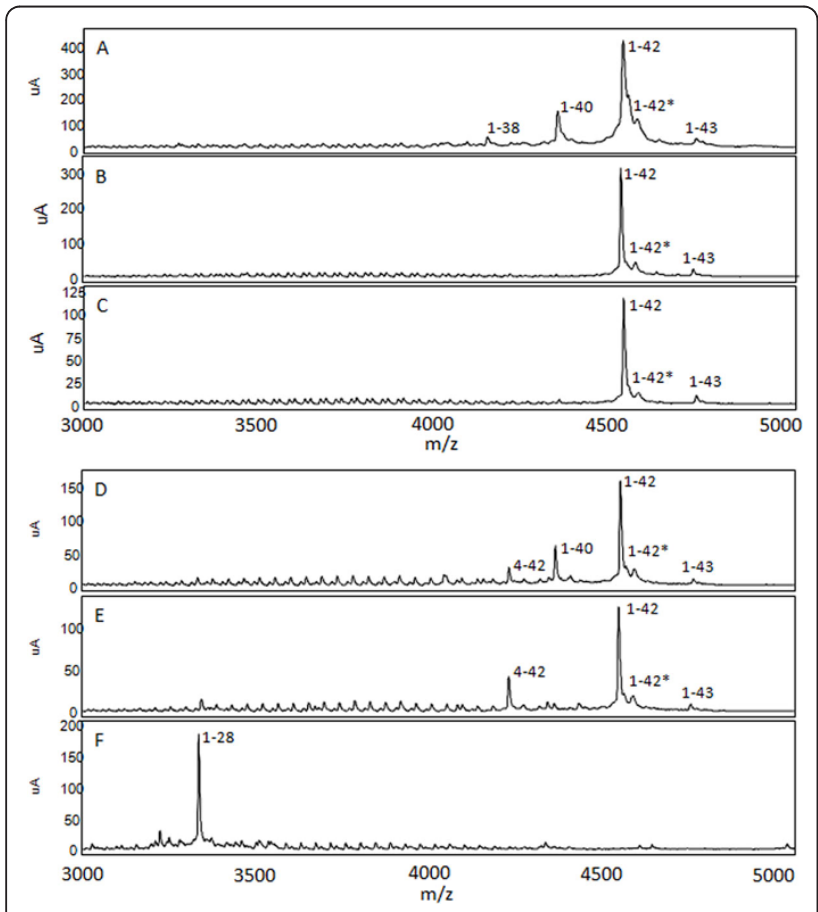

Figure 4 Mass spectrometric (MS) analysis following immunoprecipiation of $A \beta$ from $2 \%$ SDS extracted lysates of human subjects. $2 \%$ SDS lysates of Alzheimer's disease (AD; A, D), pathological aging $(\mathrm{PA} ; \mathbf{B}, \mathbf{E})$ and control $(\mathrm{NDC} ; \mathbf{C}, \mathbf{F})$ subjects were subjected to immunoprecipitation with pull-down by Ab9 (A-C), sequential pull-down with Ab9 and 4G8 (D-F). Representative MS spectra are shown (A-F). Peaks corresponding to $A \beta$ peptides have been labeled according to $\mathrm{m} / \mathrm{z}$. A $\mathrm{A} 1-28$ was spiked in as an experimental control. The $1-42^{*}$ peak denotes a possible modified $A \beta 1-42$ species (Aß1-42 + 16 Da, A-E). A $\beta$, amyloid $\beta$; SDS, sodium dodecyl sulfate. (detected by Ab9) obscure less abundant peptides, and that $\mathrm{Ab} 9$ does not capture all $\mathrm{NH}_{2}$-terminally truncated A $\beta$ peptides. Spectra from the TBS and RIPA lysates had low signal to noise ratio attributable to the low amounts $(0$ to $4 \mathrm{pmol} / \mathrm{g}$ ) of $A \beta$ in these samples limiting our ability to definitively identify $A \beta$ peptides. In contrast, high quality spectra were obtained for the vast majority of the 2\% SDS and 70\% FA extracted lysates. Representative spectra of the 2\% SDS and 70\% FA extracts after immunoprecipitation with Ab9 and 4G8 are shown in Figures 4 and 5 , respectively. In these spectra $A \beta$ species were assigned to the inferred mass based on $\mathrm{m} / \mathrm{z}$. Numerous $\mathrm{COOH}$ - and $\mathrm{NH}_{2}$-terminal fragments of $A \beta$ peptides were observed in a subset of the lysates from the AD, PA and NDC cohorts; however, few unique truncated peptides were identified in any patient group, and these 'unique' peptides were only detected in a minority of the samples in that group. Unique peptides that 1) have not been previously reported in other MS analyses of AD brains (for example, $A \beta 1-26,9-40$ and 4-40) or 2) that were uniquely
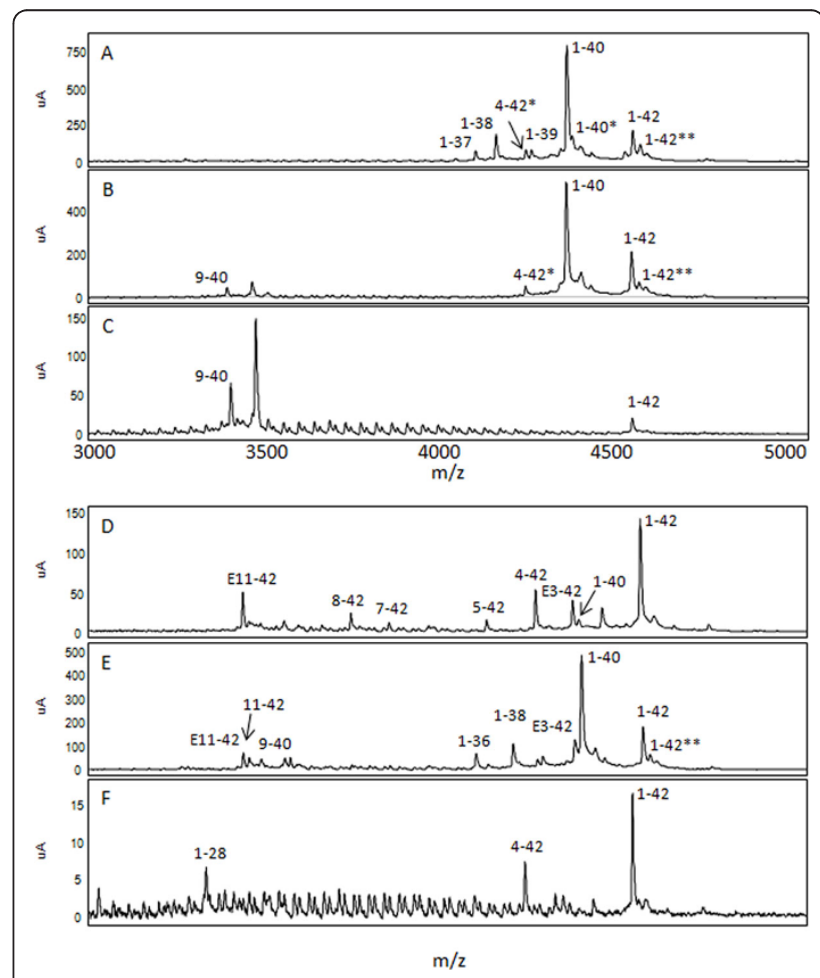

Figure 5 Mass spectrometric (MS) analysis following immunoprecipiation of $A \beta$ peptides from $70 \%$ formic acid extracted lysates of human subjects. $70 \%$ formic acid extracted lysates of Alzheimer's disease (AD; $\mathbf{A}, \mathbf{D})$, pathological aging (PA; B, E) and control (NDC; $\mathbf{C}, \mathbf{F})$ cohorts were subjected to

immunoprecipitation with pull-down by Ab9 (A-C), sequential pulldown with Ab9 and 4G8 (D-F). Representative MS spectra are shown. Peaks corresponding to $A \beta$ peptides have been labeled according to $\mathrm{m} / \mathrm{z}$. A $\beta 1-28$ was spiked in as an experimental control. Different peaks corresponding to modified $A \beta$ are shown (4-42*, $A \beta 4-42+16 \mathrm{Da}$; 1$40^{*}, A \beta 1-40+16$ Da; $1-42^{* *}, A \beta 1-42+22$ Da). $A \beta$, amyloid $\beta$. 
Table 2 Mass spectrometric analysis of SDS soluble fraction immunoprecipitated with Ab9 from human brains reveal unique $A \beta$ peaks.

\begin{tabular}{|c|c|c|c|c|c|}
\hline A $\beta$ Peptide & predicted MW & observed MW & $A D(n=16)$ & $\mathrm{PA}(\mathrm{n}=9)$ & NDC $(n=8)$ \\
\hline $1-22$ & 2661.82 & 2663.37 & & $1(11.1 \%)$ & \\
\hline $1-26$ & $\underline{3020.16}$ & $\underline{3021.17}$ & $3(18.8 \%)$ & $3(33.3 \%)$ & \\
\hline $8-40$ & 3458.98 & 3461.27 & $1(6.3 \%)$ & & \\
\hline$\underline{9-40}$ & $\underline{3371.90}$ & $\underline{3372.80}$ & & $2(22.2 \%)$ & $1(12.5 \%)$ \\
\hline $4-40$ & 4014.57 & 4016.50 & $1(6.3 \%)$ & $1(11.1 \%)$ & \\
\hline $5-42$ & $\overline{4051.57}$ & $\overline{4053.50}$ & $1(6.3 \%)$ & & \\
\hline $1-38$ & 4131.52 & 4133.95 & 1 (6.3\%) & & \\
\hline $4-42$ & 4198.74 & 4200.44 & 7 (43.8\%) & $3(33.3 \%)$ & $2(25 \%)$ \\
\hline $1-39$ & 4230.65 & 4233.33 & 1 (6.3\%) & & \\
\hline $1-40$ & 4329.78 & 4331.96 & $10(62.5 \%)$ & $3(33.3 \%)$ & $2(25 \%)$ \\
\hline $1-40+16 \mathrm{Da}$ & 4345.78 & 4345.96 & & $1(11.1 \%)$ & $2(25 \%)$ \\
\hline $1-41$ & 4442.94 & 4446.86 & 1 (6.3\%) & & \\
\hline $2-43$ & 4500.11 & 4503.58 & 1 (6.3\%) & & \\
\hline $1-42$ & 4514.02 & 4516.48 & $16(100 \%)$ & 9 (100\%) & $5(62.5 \%)$ \\
\hline $1-42+16 \mathrm{Da}$ & 4530.02 & 4531.81 & $8(50 \%)$ & $3(33.3 \%)$ & $2(25 \%)$ \\
\hline $1-43$ & 4615.20 & 4616.60 & $3(18.8 \%)$ & $1(11.1 \%)$ & $1(12.5 \%)$ \\
\hline
\end{tabular}

Human brain tissue was extracted with $2 \%$ SDS and sequentially immunoprecipitated with Ab9 and $4 \mathrm{G} 8$ antibodies to enrich different truncated or modified A $\beta$ peptides. Mass spectrometric analysis shows unique $A \beta$ peptides that 1) have not been previously reported in other mass spectrometric analyses of $A D$ brains (underlined) 2) uniquely present in AD (bold font) or PA (italicized) are differentially highlighted. Predicted molecular weights and observed molecular weights have been calculated using ExPASy PeptideMass and ProteinChip Data Manager software (Bio-Rad), respectively. The number of subjects (AD, Alzheimer's disease; PA, Pathological aging; NDC, controls) displaying each uniquely identifiable $A \beta$ peptides and the percentage of occurrence of such peptides corresponding to the total sample size is denoted. $A \beta$, amyloid $\beta ;$ MW, molecular weight; $n$, number; SDS, sodium dodecyl sulfate.

present in PA (for example, $A \beta 1-22,4-42$ and 11-42), AD (for example, A $\beta 8-40,1-37,1-38$ and 1-39) or NDC (for example, $A \beta 1-26,1-27$ and 2-42) are distinguished in Tables 2, 3, 4 and 5 by differential fonts. Though the profiles were overlapping between $\mathrm{AD}, \mathrm{PA}$ and NDC samples (Figures 4, 5, 6 and 7; Tables 2, 3, 4 and 5), there were more complex mixtures of $A \beta$ peptides observed in a subset of the AD samples versus PA and for most of the AD and PA samples relative to control. These differences typically related to minor peaks in a subset of the spectra. This did not appear to be related to absolute levels of $A \beta$ as they were similar to levels measured by ELISAs in the starting extracts. Notably, consistent with many previous studies, $A \beta 1-42$ was the only species consistently detected by the Ab9 IP/MS in all AD and PA brains.

Several modified $A \beta$ peptides, that were consistent with a $16 \mathrm{Da}$ increase in mass, were observed. This mass shift is typically indicative of oxidation. Control studies demonstrated that the methodology used did not induce oxidation of reduced synthetic $A \beta$. Thus, there was evidence that $A \beta 1-30,1-37,1-38,1-40$ and 1-42 were present in the brain as oxidized species. In most cases the peptides were detected in only a few samples among the cohort sets and there were no notable differences in the rate of detection between $\mathrm{AD}, \mathrm{PA}$ and controls. However, oxidized $A \beta$ peptides were detected more frequently in AD cases with CAA (ten of ten)

Table 3 Mass spectrometric analysis of SDS soluble fraction immunoprecipitated with 4G8 from human brains reveal unique $A \beta$ peaks.

\begin{tabular}{|c|c|c|c|c|c|}
\hline A $\beta$ Peptide & predicted MW & observed MW & $A D(n=16)$ & $\mathrm{PA}(\mathrm{n}=9)$ & $\operatorname{NDC}(n=8)$ \\
\hline $8-40$ & 3458.98 & 3462.81 & $1(6.3 \%)$ & & \\
\hline$\underline{4-40}$ & $\underline{4014.57}$ & $\underline{4018.49}$ & $1(6.3 \%)$ & & \\
\hline $4-42$ & 4198.74 & 4202.62 & $4(25.0 \%)$ & 3 (33.39\%) & $1(12.5 \%)$ \\
\hline $1-40$ & 4329.78 & 4333.49 & $3(18.8 \%)$ & & $1(12.5 \%)$ \\
\hline $1-42$ & 4514.02 & 4516.74 & $9(56.3 \%)$ & 7 (77.80\%) & $2(25 \%)$ \\
\hline $1-42+16 \mathrm{Da}$ & 4530.02 & 4534.90 & $2(12.5 \%)$ & $2(22.2 \%)$ & $2(25 \%)$ \\
\hline
\end{tabular}

Human brain tissue was extracted with $2 \%$ SDS and sequentially immunoprecipitated with Ab9 and 4 G8 antibodies to enrich different truncated or modified A 3 peptides. Mass spectrometric analysis shows unique $A \beta$ peptides that 1) have not been previously reported in other mass spectrometric analyses of $A D$ brains (underlined) 2) uniquely present in $A D$ (bold font) are differentially highlighted. Predicted molecular weights and observed molecular weights have been calculated using ExPASy PeptideMass and ProteinChip Data Manager software (Bio-Rad), respectively. The number of subjects (AD, Alzheimer's disease; PA, Pathological aging; NDC, controls) displaying each uniquely identifiable $A \beta$ peptide and the percentage of occurrence of such peptides corresponding to the total sample size is denoted. $A \beta$, amyloid $\beta ; M W$, molecular weight; $n$, number; SDS, sodium dodecyl sulfate. 
Table 4 Mass spectrometric analysis of formic acid (FA) fraction immunoprecipitated with Ab9 from human brains reveal unique $A \beta$ peaks.

\begin{tabular}{|c|c|c|c|c|c|}
\hline A $\beta$ Peptide & predicted MW & observed MW & $A D(n=16)$ & $\mathrm{PA}(\mathrm{n}=9)$ & NDC $(n=8)$ \\
\hline $1-18$ & 2167.28 & 2167.70 & $2(12.5 \%)$ & & \\
\hline $1-26$ & $\underline{3020.16}$ & $\underline{3021.02}$ & & & $2(25 \%)$ \\
\hline $\mathrm{pE} 11-40$ & 3115.65 & 3151.47 & & & 1 (12.5\%) \\
\hline $1-27$ & 3134.27 & 3134.77 & & & 1 (12.5\%) \\
\hline pE11-42 & 3317.90 & 3318.91 & $1(6.3 \%)$ & 2 (22.2\%) & \\
\hline$\underline{9-40}$ & $\underline{3371.90}$ & $\underline{3372.97}$ & $8(50 \%)$ & $6(66.7 \%)$ & $5(62.5 \%)$ \\
\hline $1-30+16 \mathrm{Da}$ & $\overline{3406.57}$ & $\overline{3409.22}$ & $1(6.3 \%)$ & & \\
\hline $1-36$ & 4017.42 & 4019.60 & $1(6.3 \%)$ & & \\
\hline $1-37$ & 4074.47 & 4076.58 & $2(12.5 \%)$ & & \\
\hline 1-37 +16 Da & 4090.47 & 4094.07 & $1(6.3 \%)$ & & \\
\hline $1-38$ & 4131.52 & 4134.52 & $4(25.0 \%)$ & & \\
\hline $1-38+16 \mathrm{Da}$ & 4147.52 & 4150.11 & $1(6.3 \%)$ & & \\
\hline $4-42$ & 4198.74 & 4200.32 & & $2(22.2 \%)$ & \\
\hline $4-42+16 \mathrm{Da}$ & 4214.74 & 4216.78 & $1(6.3 \%)$ & $1(11.1 \%)$ & $1(12.5 \%)$ \\
\hline $1-39$ & 4230.65 & 4232.14 & $2(12.5 \%)$ & $1(11.1 \%)$ & \\
\hline$\underline{3-41}$ & $\underline{4256.85}$ & $\underline{4260.60}$ & $2(12.5 \%)$ & $1(11.1 \%)$ & \\
\hline pE3-42 & 4309.90 & 4312.76 & & $1(11.1 \%)$ & \\
\hline $1-40$ & 4329.78 & 4332.14 & $12(75.0 \%)$ & $6(66.7 \%)$ & $2(25 \%)$ \\
\hline $1-40+16 \mathrm{Da}$ & 4345.78 & 4347.41 & 7 (43.8\%) & 1 (11.1\%) & $1(12.5 \%)$ \\
\hline $2-42$ & 4395.93 & 4399.63 & & & 1 (12.5\%) \\
\hline $1-41$ & 4442.94 & 4444.51 & 1 (6.3\%) & 1 (11.1\%) & \\
\hline $1-42$ & 4514.02 & 4516.58 & $16(100 \%)$ & $9(100 \%)$ & $4(50 \%)$ \\
\hline $1-42+16 \mathrm{Da}$ & 4530.02 & 4532.13 & 9 (56.3\%) & 4 (44.4\%) & 1 (12.5\%) \\
\hline $1-43$ & 4615.20 & 4617.58 & $4(25.0 \%)$ & $3(33.3 \%)$ & $1(12.5 \%)$ \\
\hline
\end{tabular}

Human brain tissue, extracted with 70\% FA, was sequentially immunoprecipitated with Ab9 and $4 \mathrm{G} 8$ antibodies to enrich different truncated or modified A $\beta$ species. Mass spectrometric analysis shows unique $A \beta$ peptides that 1) have not been previously reported in other mass spectrometric analyses of AD brains (underlined) 2) uniquely present in AD (bold font), PA (italicized font) or controls (bold and italicized font) are differentially highlighted. Predicted molecular weights and observed molecular weights have been calculated using ExPASy PeptideMass and ProteinChip Data Manager software (Bio-Rad), respectively. The number of subjects (AD, Alzheimer's. disease; PA, Pathological aging; NDC, controls) displaying each uniquely identifiable A $\beta$ peptide and the percentage of occurrence of such peptide corresponding to the total sample size is denoted. $A \beta$, amyloid $\beta$; MW, molecular weight; $n$, number.

compared to cases without CAA (one of six). This association was not apparent in PA where oxidized A $\beta$ peptides were detected in two of four cases with and three of five cases without CAA. Three peaks, consistent with pyroglutamate $A \beta$, were detected in the $70 \%$ FA fraction of $\mathrm{AD}, \mathrm{PA}$ and controls: $\mathrm{A} \beta \mathrm{pE} 11-40, \mathrm{~A} \beta \mathrm{pE} 11-42$ and $A \beta p E 3-42$. These species were not detected in the $2 \%$ SDS lysates suggesting that they are highly insoluble.

\section{Immunoblotting analysis of $\boldsymbol{A} \boldsymbol{\beta}$ species}

We next analyzed these samples by SDS-PAGE followed by Western Blot. The representative blots shown were separated by electrophoresis, transferred to nitrocellulose, not boiled and stained with 82E1 antibody (anti$\mathrm{A} \beta 1-16)$ (IBL). We found that this method gave the most sensitive detection and, based on estimates, our detection limit was 1 to 10 pmol monomeric $A \beta$. A number of Western Blots failed to differentiate oligomer assemblies between PA and AD in TBS and 2\% SDS lysates (Figure 8) and RIPA lysates (Figure 9). We detected a $10 \mathrm{kDa}$ band in the TBS and RIPA lysates of
$\mathrm{AD}, \mathrm{PA}$ and NDC cohorts. This band could be an oligomeric assembly of $A \beta$, an APP $\beta$-C-terminal fragment (since there is cross-reactivity of these two species with $82 \mathrm{E} 1$ ) or a non-specific band. This band was consistently detected with other anti-A $\beta$ antibodies, although these other antibodies had lower limits of sensitivity.

\section{Discussion}

In this study we systematically characterized $A \beta$ levels and solubility, peptide profiles and oligomeric assemblies in a postmortem series of PA, AD and NDC cohorts. Using a panel of $A \beta$ sandwich ELISAs we appraised the levels of $A \beta 1-40, A \beta 1-42$ and $A \beta$ total, as well as $A \beta x-$ 42. We found extensive overlap in $A \beta$ levels between $\mathrm{AD}$ and PA brains. On average, $\mathrm{AD}$ and PA lysates contained much more $A \beta$ than NDC samples. $A \beta$ levels in PA lysates were similar to the levels in the AD lysates, ranging from almost equivalent to approximately $50 \%$ less than the $\mathrm{A} \beta$ detected in $\mathrm{AD}$ lysates and solubility profiles were similar with the vast majority of $A \beta$ in PA and $\mathrm{AD}$ requiring either SDS or FA to solubilize. 
Table 5 Mass spectrometric analysis of formic acid (FA) fraction immunoprecipitated with $4 \mathrm{G} 8$ from human brains reveal unique $A \beta$ peaks.

\begin{tabular}{|c|c|c|c|c|c|}
\hline$A \beta$ Peptide & predicted MW & observed MW & $A D(n=16)$ & $\mathrm{PA}(\mathrm{n}=9)$ & $\operatorname{NDC}(n=8)$ \\
\hline $1-18$ & 2167.28 & 2165.21 & $1(6.3 \%)$ & & \\
\hline $1-27$ & 3134.27 & 3135.30 & $1(6.3 \%)$ & & \\
\hline E11-42 & 3317.90 & 3320.02 & $8(50.0 \%)$ & 7 (77.8\%) & $1(12.5 \%)$ \\
\hline $1-29$ & 3319.49 & 3320.87 & $1(6.3 \%)$ & & \\
\hline $11-42$ & 3335.90 & 3328.79 & & $1(11.1 \%)$ & \\
\hline$\underline{9-40}$ & $\underline{3371.90}$ & $\underline{3373.39}$ & $3(18.8 \%)$ & $5(55.6 \%)$ & $4(50 \%)$ \\
\hline$\underline{8-40}$ & $\underline{3458.98}$ & $\underline{3460.65}$ & $1(6.3 \%)$ & $1(11.1 \%)$ & \\
\hline $1-31$ & 3503.72 & 3503.55 & $1(6.3 \%)$ & & \\
\hline $9-42$ & 3556.08 & 3557.85 & $1(6.3 \%)$ & & \\
\hline $8-42$ & 3643.15 & 3644.86 & $5(31.3 \%)$ & & $1(12.5 \%)$ \\
\hline $7-42$ & 3758.24 & 3758.89 & $2(12.5 \%)$ & & \\
\hline $1-34$ & 3787.09 & 3786.56 & 1 (6.3\%) & & \\
\hline $1-35$ & 3918.29 & 3918.96 & 1 (6.3\%) & & \\
\hline$\underline{4-40}$ & $\underline{4014.57}$ & $\underline{4016.85}$ & $1(6.3 \%)$ & $1(11.1 \%)$ & \\
\hline $1-36$ & 4017.42 & 4018.25 & $1(6.3 \%)$ & 1 (11.1\%) & \\
\hline $5-42$ & 4051.57 & 4053.59 & $4(25.0 \%)$ & & $1(12.5 \%)$ \\
\hline $1-37$ & 4074.47 & 4075.25 & $1(6.3 \%)$ & & \\
\hline $1-38$ & 4131.52 & 4131.33 & $1(6.3 \%)$ & $1(11.1 \%)$ & \\
\hline $4-42$ & 4198.74 & 4201.29 & & $5(55.6 \%)$ & $2(25 \%)$ \\
\hline 4-42 +16 Da & 4214.74 & 4217.09 & $2(12.5 \%)$ & $1(11.1 \%)$ & \\
\hline $1-39$ & 4230.65 & 4231.46 & 1 (6.3\%) & & \\
\hline E3-42 & 4309.90 & 4312.76 & $4(25.0 \%)$ & $3(33.3 \%)$ & 1 (12.5\%) \\
\hline $1-40$ & 4329.78 & 4331.85 & $8(50.0 \%)$ & $5(55.6 \%)$ & $2(25 \%)$ \\
\hline $1-40+16 \mathrm{Da}$ & 4345.78 & 4348.09 & $4(25.0 \%)$ & & \\
\hline $1-42$ & 4514.02 & 4516.70 & $10(62.5 \%)$ & 7 (77.8\%) & $4(50 \%)$ \\
\hline $1-42+16 \mathrm{Da}$ & 4530.02 & 4533.03 & & & 1 (12.5\%) \\
\hline
\end{tabular}

Human brain tissue, extracted with 70\% FA, was sequentially immunoprecipitated with Ab9 and $4 \mathrm{G} 8$ antibodies to enrich different truncated or modified A $\beta$ species. Mass spectrometric analysis shows unique $A \beta$ peptides that 1) have not been previously reported in other mass spectrometric analyses of $A D$ brains (underlined) 2) uniquely present in AD (bold font), PA (italicized font) or controls (bold and italicized font) are differentially highlighted. Predicted molecular weights and observed molecular weights have been calculated using ExPASy PeptideMass and ProteinChip Data Manager software (Bio-Rad), respectively. The number of subjects (AD, Alzheimer's disease; PA, Pathological aging; NDC, controls) displaying each uniquely identifiable $A \beta$ peptide and the percentage of occurrence of such peptide corresponding to the total sample size is denoted. $A \beta$, amyloid $\beta ; M W$, molecular weight; $n$, number.

We examined $A \beta$ peptide profiles by IP/MS in $A D$, PA and NDC patient brain lysates. A $\beta 1-42$ was identified as the predominant peak in the SDS and FA 'insoluble' fractions across all groups. As noted above, it was the only $\mathrm{A} \beta$ peptide detected by IP/MS in all PA and $\mathrm{AD}$ cases. In addition, several unique $\mathrm{NH}_{2}$ - and $\mathrm{COOH}-$ terminal truncated $A \beta$ peptides were observed in the AD brain lysates. However, few unique truncated $A \beta$ peptides were observed in any one patient group and these peptides represented minor peaks. These truncated peptides may represent alternate cleavage products by $\beta$ - and $\gamma$-secretases or products of $A \beta$ degradation.

Interestingly, we detected peaks that correspond to A $\beta 1-30,1-37,1-38,1-40$ and 1-42 with a 16 Da mass shift that we hypothesize to be oxidation products of $A \beta$. Oxidation of these $A \beta$ peptides could be an artifact due to the extraction and IP/MS techniques utilized in this study; however, this is unlikely since we did not observe the mass shift in other detected $A \beta$ peptides or in control IP/MS studies using reduced synthetic $A \beta$. Although $\mathrm{A} \beta$ is composed of several amino acids that could be oxidized, most studies have suggested oxidation occurs primarily at the methionine residue at position 35 (Met-35) [40]. A number of studies suggest that oxidized $A \beta$ peptides are present in the brain and that oxidation of $A \beta 1-42$ decreases the rate of aggregation, disrupts fibril morphology and inhibits oligomerization [41,42]. Oxidized $A \beta$ peptides were observed as minor peaks in the spectra, indicating that these represent a minor fraction of total $A \beta$ since control studies showed that both peptides ionized at the same levels. There were no striking differences in oxidized peptides between $\mathrm{AD}$ and PA patients. However, remarkably all of the $A D$ patients with $C A A$ had oxidized $A \beta$ peptides while only one of six AD patients without CAA had oxidized $A \beta$ peptides.

We detected peaks corresponding to pyroglutamate modified $\mathrm{A} \beta(\mathrm{A} \beta \mathrm{pE})$, at position 11, $\mathrm{A} \beta \mathrm{pE} 11-40$, 

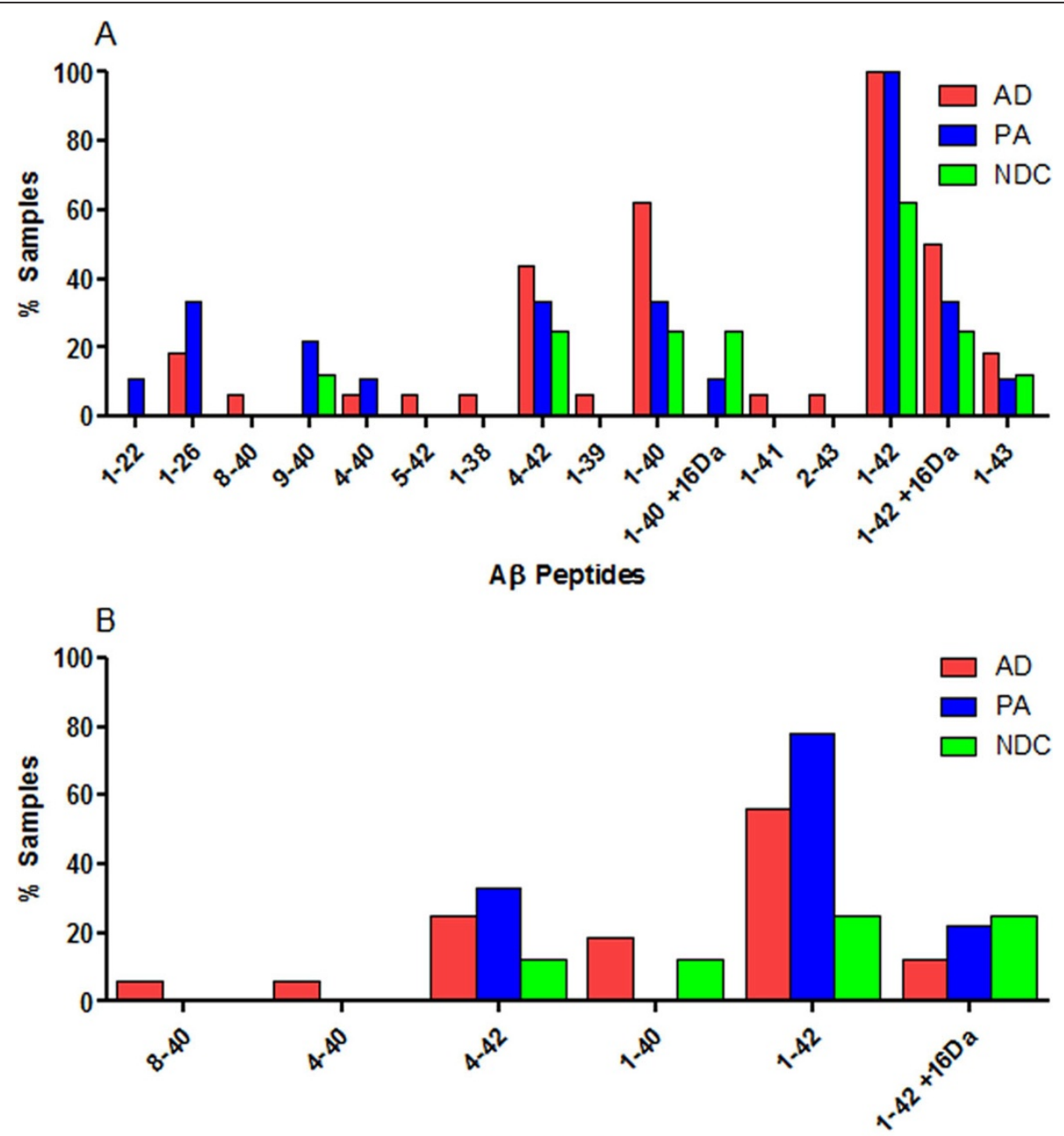

A $\beta$ Peptides

Figure 6 Summary of SDS soluble $\mathbf{A} \boldsymbol{\beta}$ peptides in test subjects. 2\% SDS extracted lysates from human prefrontal cortical tissues were subjected to immunoprecipitation with pull-down by Ab9 (A) or sequential pull-down with Ab9 and 4G8 (B), followed by MS. Data are graphically presented as a percentage of subjects in each cohort (Alzheimer's disease (AD), Pathological aging (PA) or controls (NDC)) containing A $\beta$ peptides (x-axis). $N=16(A D), 8(P A)$ and 6 (NDC). A $\beta$, amyloid $\beta$; MS, mass spectrometry; $N$, number; SDS, sodium dodecyl sulfate.

$\mathrm{A} \beta \mathrm{pE} 11-42$, and at position $3, \mathrm{~A} \beta \mathrm{pE} 3-42$, in the insoluble lysates of $\mathrm{AD}$, PA and NDC. A $\beta \mathrm{pE}$ is formed by glutamate cyclization at position 11 by glutaminyl cyclase [43]. The conversion of glutamate to pyroglutamate is reported to protect the $A \beta$ peptide from degradation through resistance to aminopeptidases [44]. $\mathrm{A} \beta \mathrm{pE}$ is also reported to be highly prone to oligomerization and can possibly seed the oligomerization and fibrillation process of full-length $A \beta$ species $[18,20,45]$. Based on these data as well as other studies examining $A \beta p E$ levels and animal modeling studies that manipulate $\mathrm{A} \beta \mathrm{pE}$ levels, an initiating role for $\mathrm{A} \beta \mathrm{pE}$ in $\mathrm{AD}$ has been proposed [46-50]. Although our detection of $\mathrm{A} \beta \mathrm{pE}$ in a control brain would not be inconsistent with a postulated role in seeding aggregation, its presence in some PA brains suggest that its toxicity is not inherently different from other aggregated $A \beta$ peptides.

There is currently much debate regarding which types of $A \beta$ aggregates are the most toxic. $A \beta$ rapidly forms stable fibrillar amyloid structures, which account for much of the $A \beta$ that accumulates in the AD brain. Over the last decade, a variety of soluble oligomeric species, including dimers, trimers, tetramers and 10-12-mers have been identified and isolated [35,51-53]. These oligomers have been shown to be biologically active as they inhibit hippocampal long-term potentiation and create memory impairments when injected into rodents $[35,53,54]$. Additional circumstantial data suggests that oligomeric assemblies may account for some of the behavioral deficits observed in APP mice [55]. As there 

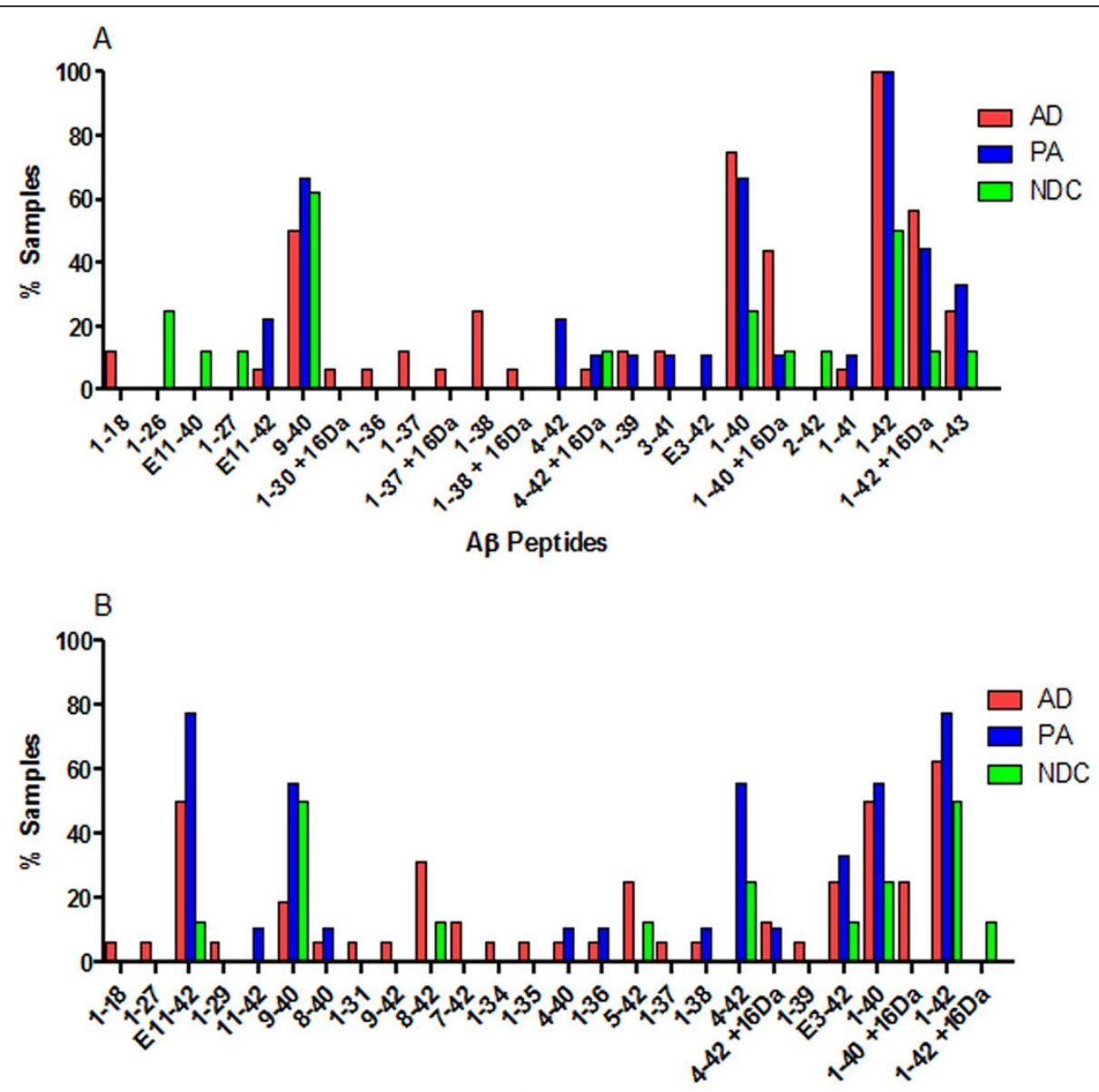

A $\beta$ Peptides

Figure 7 Summary of formic acid soluble $\mathbf{A} \boldsymbol{\beta}$ peptides in test subjects. 70\% FA extracted lysates from human prefrontal cortical tissue were subjected to immunoprecipitation with pull-down by Ab9 (A) or sequential pull-down with Ab9 and 4G8 (B), followed by MS. Data are graphically presented as a percentage of subjects in each cohort (Alzheimer's disease (AD), Pathological aging (PA) or controls (NDC)) containing $A \beta$ peptides (x-axis). $N=16(A D), 8(P A)$ and 6 (NDC). A $\beta$, amyloid $\beta$; FA, formic acid; $M S$, mass spectrometry; $N$, number.

is no standard methodology to detect oligomeric assemblies, we empirically settled on a method that was the most sensitive in our hands, and also would enable us to survey oligomeric assemblies in multiple brain lysates. This survey revealed that there were no obvious differences in higher molecular weight bands between $\mathrm{AD}$, PA and NDC. Our data are consistent with a recent publication that reported a more extensive analysis of oligomeric assemblies and also failed to detect major differences in PA and AD [34]. Indeed, it is not the relatively small increases in the TBS and RIPA extractable $\mathrm{A} \beta$ pools but that of the SDS and 70\% FA extractable insoluble $A \beta$ pools that clearly distinguish both $A D$ and PA from controls.

\section{Conclusions}

In summary, we investigated $A \beta$ levels, peptides and assemblies from soluble, detergent-soluble and insoluble pools from AD, PA and NDC brain. We found only subtle quantitative differences between $\mathrm{PA}$ and $\mathrm{AD}$ brains that, in most cases, did not reach significance. We found overlap between the PA and AD A $\beta$ peptide profile, as examined by IP/MS, but AD patients contained additional amino terminal truncated $A \beta$ peptides. There were no major differences observed in SDS-stable $\mathrm{A} \beta$ oligomeric assemblies. We cannot rule out the possibility that there are conformational differences or very subtle differences in minor $A \beta$ peptides or assemblies that distinguish AD from PA; however, our data, which shows extensive similarities between deposited $A \beta$ in $\mathrm{AD}$ and PA, would indicate that PA is not likely to represent a form of benign $A \beta$ deposition. Indeed, our data are more consistent with the hypothesis that PA represents an initial prodromal stage of $\mathrm{AD}$ and that these individuals would eventually go on to develop clinical symptoms, if they live long enough $[31,32]$. 


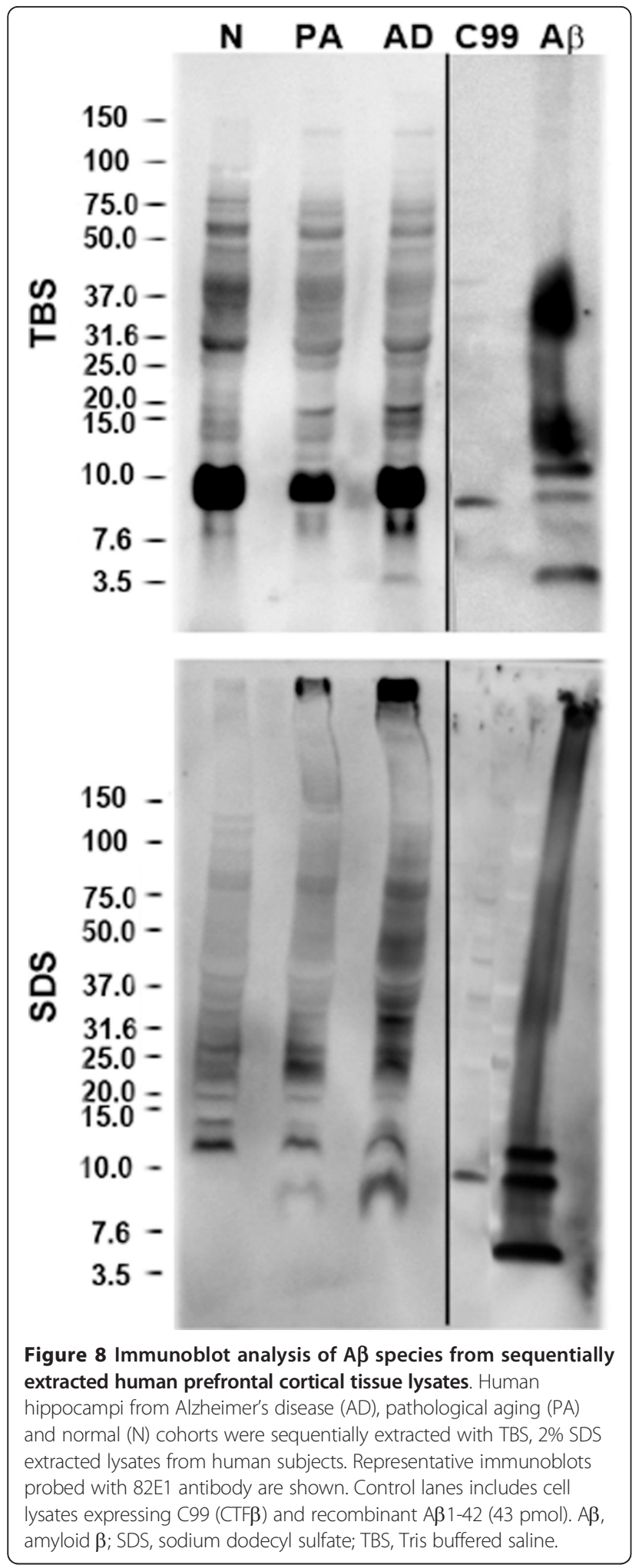

Notably, PA brains do not completely lack cortical tau pathology; however, pathological phospho-tau levels are present in lower levels compared to AD (Figure 1). Indeed, given predictions of the amyloid cascade
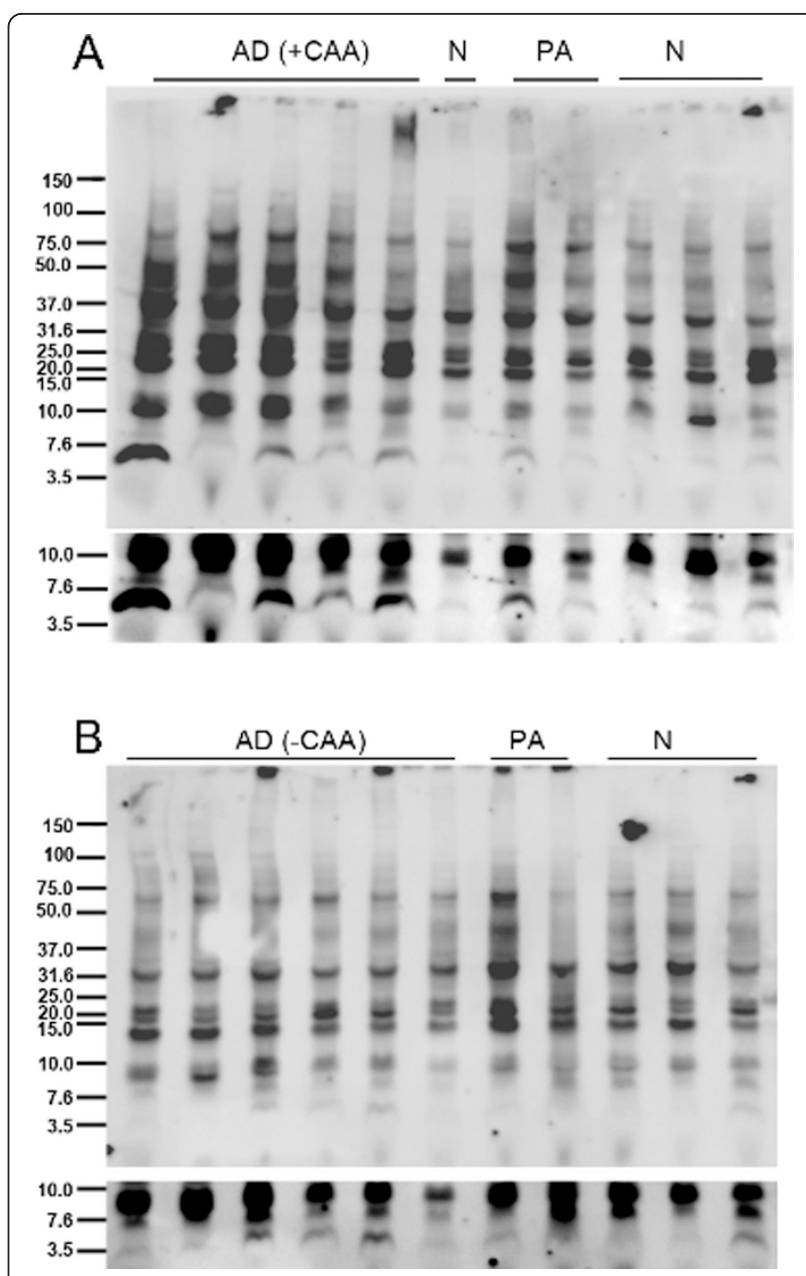

Figure 9 Immunoblot analysis of $A \beta$ species from RIPA soluble lysates from human subjects. Human hippocampi from Alzheimer's disease (AD), pathological aging (PA) and normal (N) cohorts were extracted with RIPA. Representative anti-82E1 immunoblot of RIPA extracted lysates of Alzheimer's disease (AD), pathologic aging (PA) and control (N) subjects with $(\mathbf{A})$ and without (B) a post-mortem clinical pathological diagnosis of cerebral amyloid angiopathy (+CAA). Longer exposure panels below highlight no significant differences between the three cohorts in the dimer/trimer molecular weight range. $A \beta$, amyloid $\beta$; RIPA, radioimmunoprecipitation buffer.

hypothesis, many of which are being demonstrated in living humans via imaging and cerebrospinal fluid studies, one would predict that a subset of cognitively normal subjects would die with heavy amyloid loads but limited tau pathology $[56,57]$. This possibility needs to be taken into account in the debate regarding identification of the toxic $A \beta$ species. We should not discount the role of insoluble fibrillar assemblies in driving downstream pathologies; assemblies may produce an insidious form of cellular toxicity that may be difficult to assess in more acute experimental models. This concept may best be phrased that amyloid-like assemblies are necessary 
but not sufficient to drive neurodegeneration. Although speculative, it is also possible that PA patients may be protected from the downstream effects of $A \beta$. In the latter case, genetic studies, gene expression profiling, or perhaps even development of induced pluripotent stem cells from PA subjects could identify factors that confer protection from $A \beta$. Ultimately, in order to determine whether PA represents a prodromal phase of AD or could reflect inherent resistance to $A \beta$, long-term longitudinal amyloid imaging, biomarker studies, and postmortem neuropathological examination will be needed. If powered sufficiently such studies could determine whether there are subsets of individuals who develop AD-like plaque pathology but retain normal cognitive function without neurodegeneration after extended periods of time or whether parenchymal $A \beta$ accumulation invariably leads to neurodegeneration and $\mathrm{AD}$.

\section{Additional material}

Additional file 1: Figure S1. Biochemical analysis of $A \beta$ levels from human brain lysates. $A$ panel of sandwich ELISAs measuring $A \beta 1-40$ $A \beta 1-42, A \beta$ total and $A \beta x-42$ from brain lysates sequentially extracted with TBS (A), RIPA (B), $2 \%$ SDS (C) and $70 \%$ formic acid (D) is shown. Data are presented as scatter dot plots, $n=16(\mathrm{AD}), 8(\mathrm{PA})$ and $6(\mathrm{NDC})$. $\left({ }^{* *} P<0.001,{ }^{* *} P<0.01,{ }^{*} P<0.05\right.$ by ANOVA with tukey post-hoc analysis raw data analyzed (A, B) and log-transformed data analyzed (C, D)).

\section{Abbreviations \\ A 3 : amyloid-beta; AD: Alzheimer's disease; APP: amyloid $\beta$ protein precursor; CAA: cerebral amyloid angiopathy; ELISA: enzyme-linked immunosorbent assay; FA: formic acid; HRP: horseradish peroxidase; IP/MS: immunoprecipitation/mass spectrometry; mAb: monoclonal antibody; PA: pathological aging; NDC: non-demented controls; RIPA: radioimmunoprecipitation buffer; SDS: sodium dodecyl sulfate; TBS: Tris buffered saline.}

\section{Acknowledgements}

We are grateful to all patients, family members and caregivers who agreed to brain donation, without which these studies would not have been possible. We also acknowledge the expert technical assistance of Monica Casey-Castanedes, Linda Rousseau and Virginia Phillips for immunohistochemistry and for histology. This research was funded by the Mayo Clinic Alzheimer's Disease Research Center Pilot Project Grant (AG16574) and the NIH AG20206 (TEG)

\section{Author details}

'Center for Translational Research in Neurodegenerative Disease, Department of Neuroscience, McKnight Brain Institute, College of Medicine, University of Florida, 1275 Center Drive, Gainesville, FL, 32610, USA.

${ }^{2}$ Department of Pharmacology, Emory University School of Medicine, 1510 Clifton Road, Atlanta, GA, 30322, USA. ${ }^{3}$ Department Of Neuroscience, Mayo Clinic College of Medicine, 4500 San Pablo Road, Jacksonville, FL, 32224, USA.

\section{Authors' contributions}

BDM, TEG and PD conceived and designed the study. DWD provided human samples and contributed to critical discussions. BDM, PC, AMB, TM and TL prepared samples and acquired data. BDM and TEG drafted the manuscript. BDM, PC, YL, TK, PD and TEG contributed to the interpretation of findings. All authors read and approved the final manuscript.

\section{Competing interests}

The authors declare that they have no competing interests.

Received: 8 March 2012 Revised: 17 April 2012 Accepted:I 23 May 2012 Published: 23 May 2012

\section{References}

1. Dickson DW, Crystal HA, Bevona C, Honer W, Vincent I, Davies P: Correlations of synaptic and pathological markers with cognition of the elderly. Neurobiol Aging 1995, 16:285-298, discussion 298-304.

2. Dickson DW, Crystal HA, Mattiace LA, Masur DM, Blau AD, Davies P, Yen SH, Aronson MK: Identification of normal and pathological aging in prospectively studied nondemented elderly humans. Neurobiol Aging 1992, 13:179-189.

3. Golde TE, Dickson DW, Hutton M: Filling the gaps in the Ab cascade hypothesis of Alzheimer's disease. Curr Alz Res 2006, 3:421-430.

4. Dubois B, Feldman HH, Jacova C, Cummings JL, Dekosky ST, BarbergerGateau P, Delacourte A, Frisoni G, Fox NC, Galasko D, Gauthier S, Hampel H, Jicha GA, Mequro K, O'Brien J, Pasquier F, Robert P, Rossor M, Salloway $S$, Sarazin M, de Souza LC, Stern Y, Visser PJ, Scheltens P: Revising the definition of Alzheimer's disease: a new lexicon. Lancet Neurol 2010, 9:1118-1127.

5. Reinhard C, Hebert SS, De Strooper B: The amyloid-beta precursor protein: integrating structure with biological function. Embo J 2005, 24:3996-4006.

6. De Strooper B, Vassar R, Golde T: The secretases: enzymes with therapeutic potential in Alzheimer disease. Nat Rev Neurol 2010, 6:99-107.

7. Lewis PA, Perez-Tur J, Golde TE, Hardy J: The presenilin 1 C92S mutation increases abeta 42 production. Biochem Biophys Res Commun 2000, 277:261-263.

8. Wang R, Sweeney D, Gandy SE, Sisodia SS: The profile of soluble amyloid beta protein in cultured cell media. Detection and quantification of amyloid beta protein and variants by immunoprecipitation-mass spectrometry. J Biol Chem 1996, 271:31894-31902.

9. Younkin SG: The role of A beta 42 in Alzheimer's disease. J Physiol Paris 1998, 92:289-292.

10. Saito T, Suemoto T, Brouwers N, Sleegers K, Funamoto S, Mihira N, Matsuba Y, Yamada K, Nilsson P, Takano J, Nishimura M, Iwata N, Van Broeckhoven C, Ihara Y, Saido TC: Potent amyloidogenicity and pathogenicity of Abeta43. Nat Neurosci 2011, 14:1023-1032.

11. Lewczuk P, Esselmann H, Groemer TW, Bibl M, Maler JM, Steinacker P, Otto M, Kornhuber J, Wiltfang J: Amyloid beta peptides in cerebrospinal fluid as profiled with surface enhanced laser desorption/ionization timeof-flight mass spectrometry: evidence of novel biomarkers in Alzheimer's disease. Biol Psychiatry 2004, 55:524-530.

12. Lewczuk P, Esselmann H, Meyer M, Wollscheid V, Neumann M, Otto M, Maler JM, Ruther E, Kornhuber J, Wiltfang J: The amyloid-beta (Abeta) peptide pattern in cerebrospinal fluid in Alzheimer's disease: evidence of a novel carboxyterminally elongated Abeta peptide. Rapid Commun Mass Spectrom 2003, 17:1291-1296.

13. Wiltfang J, Esselmann H, Cupers P, Neumann M, Kretzschmar H, Beyermann M, Schleuder D, Jahn H, Ruther E, Kornhuber J, Annaert W, De Strooper B, Saftiq P: Elevation of beta-amyloid peptide 2-42 in sporadic and familial Alzheimer's disease and its generation in PS1 knockout cells. J Biol Chem 2001, 276:42645-42657.

14. Head E, Garzon-Rodriguez W, Johnson JK, Lott IT, Cotman CW, Glabe C: Oxidation of Abeta and plaque biogenesis in Alzheimer's disease and Down syndrome. Neurobiol Dis 2001, 8:792-806.

15. Naslund J, Schierhorn A, Hellman U, Lannfelt L, Roses AD, Tjernberg LO, Silberring J, Gandy SE, Winblad B, Greengard P, Nordstedt C, Terenius L: Relative abundance of Alzheimer A beta amyloid peptide variants in Alzheimer disease and normal aging. Proc Natl Acad Sci USA 1994, 91:8378-8382.

16. Kuo YM, Beach TG, Sue LI, Scott S, Layne K, Kokjohn TA, Kalback WM, Luehrs DC, Vishnivetskaya TA, Abramowski D, Sturchler-Pierrat C, Staufenbiel M, Weller RO, Roher AE: The evolution of A beta peptide burden in the APP23 transgenic mice: implications for A beta deposition in Alzheimer disease. Mol Med 2001, 7:609-618.

17. Boutte AM, Woltjer RL, Zimmerman L, Stamer SL, Montine KS, Manno MV, Cimino PJ, Liebler DC, Montine TJ: Selectively increased oxidative modifications mapped to detergent-insoluble forms of Abeta and betaIII tubulin in Alzheimer's disease. FASEB J 2006, 20:1473-1483. 
18. He W, Barrow CJ: The A beta 3-pyroglutamyl and 11-pyroglutamyl peptides found in senile plaque have greater beta-sheet forming and aggregation propensities in vitro than full-length A beta. Biochemistry 1999, 38:10871-10877.

19. Russo C, Violani E, Salis S, Venezia V, Dolcini V, Damonte G, Benatti U, D'Arrigo C, Patrone E, Carlo P, Schettini G: Pyroglutamate-modified amyloid beta-peptides-AbetaN3(pE)-strongly affect cultured neuron and astrocyte survival. J Neurochem 2002, 82:1480-1489.

20. Schilling S, Lauber T, Schaupp M, Manhart S, Scheel E, Bohm G, Demuth HU: On the seeding and oligomerization of pGlu-amyloid peptides (in vitro). Biochemistry 2006, 45:12393-12399.

21. Wirths $\mathrm{O}$, Breyhan $\mathrm{H}$, Cynis $\mathrm{H}$, Schilling $\mathrm{S}$, Demuth HU, Bayer TA: Intraneuronal pyroglutamate-Abeta 3-42 triggers neurodegeneration and lethal neurological deficits in a transgenic mouse model. Acta Neuropathol 2009, 118:487-496.

22. Hartlage-Rubsamen M, Morawski M, Waniek A, Jager C, Zeitschel U, Koch B, Cynis H, Schilling S, Schliebs R, Demuth HU, Rossner S: Glutaminyl cyclase contributes to the formation of focal and diffuse pyroglutamate (pGlu)Abeta deposits in hippocampus via distinct cellular mechanisms. Acta Neuropathol 2011, 121:705-719.

23. Harper JD, Lansbury PT Jr: Models of amyloid seeding in Alzheimer's disease and scrapie: mechanistic truths and physiological consequences of the time-dependent solubility of amyloid proteins. Annu Rev Biochem 1997, 66:385-407.

24. Lomakin A, Teplow DB, Kirschner DA, Benedek GB: Kinetic theory of fibrillogenesis of amyloid beta-protein. Proc Natl Acad Sci USA 1997 94:7942-7947.

25. Hardy J, Selkoe DJ: The amyloid hypothesis of Alzheimer's disease: progress and problems on the road to therapeutics. Science 2002, 297:353-356

26. Hartley DM, Walsh DM, Ye CP, Diehl T, Vasquez S, Vassilev PM, Teplow DB, Selkoe DJ: Protofibrillar intermediates of amyloid beta-protein induce acute electrophysiological changes and progressive neurotoxicity in cortical neurons. J Neurosci 1999, 19:8876-8884.

27. Klein WL, Krafft GA, Finch CE: Targeting small Abeta oligomers: the solution to an Alzheimer's disease conundrum? Trends Neurosci 2001, 24:219-224.

28. Westerman MA, Cooper-Blacketer D, Mariash A, Kotilinek L, Kawarabayashi T, Younkin LH, Carlson GA, Younkin SG, Ashe KH: The relationship between Abeta and memory in the Tg2576 mouse model of Alzheimer's disease. J Neurosci 2002, 22:1858-1867.

29. Kawarabayashi T, Shoji M, Younkin LH, Wen-Lang L, Dickson DW, Murakami T, Matsubara E, Abe K, Ashe KH, Younkin SG: Dimeric amyloid beta protein rapidly accumulates in lipid rafts followed by apolipoprotein $\mathrm{E}$ and phosphorylated tau accumulation in the Tg2576 mouse model of Alzheimer's disease. J Neurosci 2004, 24:3801-3809.

30. McGowan E, Pickford F, Kim J, Onstead L, Eriksen J, Yu C, Skipper L, Murphy MP, Beard J, Das P, Jansen K, Delucia M, Lin WL, Dolios G, Wang R, Eckman CB, Dickson DW, Hutton M, Hardy J, Golde T: Abeta42 is essential for parenchymal and vascular amyloid deposition in mice. Neuron 2005, 47:191-199.

31. Golde TE, Schneider LS, Koo EH: Anti-abeta therapeutics in Alzheimer's disease: the need for a paradigm shift. Neuron 2011, 69:203-213.

32. Jack CR Jr, Lowe VJ, Weigand SD, Wiste HJ, Senjem ML, Knopman DS, Shiung MM, Gunter JL, Boeve BF, Kemp BJ, Weiner M, Petersen RC: Serial $\mathrm{PIB}$ and $\mathrm{MRI}$ in normal, mild cognitive impairment and Alzheimer's disease: implications for sequence of pathological events in Alzheimer's disease. Brain 2009, 132:1355-1365.

33. Wang J, Dickson DW, Trojanowski JQ, Lee VM: The levels of soluble versus insoluble brain Abeta distinguish Alzheimer's disease from normal and pathologic aging. Exp Neurol 1999, 158:328-337.

34. Maarouf CL, Daugs ID, Kokjohn TA, Walker DG, Hunter JM, Kruchowsky JC, Woltjer R, Kaye J, Castano EM, Sabbagh MN, Beach TG, Roher AE: Alzheimer's disease and non-demented high pathology control nonagenarians: comparing and contrasting the biochemistry of cognitively successful aging. PLOS One 2011, 6:e27291.

35. Shankar GM, Li S, Mehta TH, Garcia-Munoz A, Shepardson NE, Smith I, Brett FM, Farrell MA, Rowan MJ, Lemere CA, Walsh DM, Sabatini BL, Selkoe DJ: Amyloid-beta protein dimers isolated directly from Alzheimer's brains impair synaptic plasticity and memory. Nat Med 2008, 14:837-842.
36. Saido TC, Yokota M, Tani E, Kawashima S: Alzheimer's Disease: Biology, Diagnosis and Therapeutics New York: Wiley; 1997.

37. Schmidt ML, DiDario AG, Otvos L Jr, Hoshi N, Kant JA, Lee VM, Trojanowski JQ: Plaque-associated neuronal proteins: a recurrent motif in neuritic amyloid deposits throughout diverse cortical areas of the Alzheimer's disease brain. Exp Neurol 1994, 130:311-322.

38. Kawarabayashi T, Younkin LH, Saido TC, Shoji M, Ashe KH, Younkin SG: Agedependent changes in brain, CSF, and plasma amyloid (beta) protein in the Tg2576 transgenic mouse model of Alzheimer's disease. J Neurosci 2001, 21:372-381.

39. Kim J, Miller VM, Levites Y, West KJ, Zwizinski CW, Moore BD, Troendle FJ, Bann M, Verbeeck C, Price RW, Smithson L, Sonoda L, Wagg K, Rangachari V, Zou F, Younkin SG, Graff-Radford N, Dickson D, Rosenberry T, Golde TE: BRI2 (ITM2b) inhibits Abeta deposition in vivo. J Neurosci 2008, 28:6030-6036.

40. Butterfield DA, Kanski J: Methionine residue 35 is critical for the oxidative stress and neurotoxic properties of Alzheimer's amyloid beta-peptide 142. Peptides 2002, 23:1299-1309.

41. Hou L, Kang I, Marchant RE, Zagorski MG: Methionine 35 oxidation reduces fibril assembly of the amyloid abeta-(1-42) peptide of Alzheimer's disease. J Biol Chem 2002, 277:40173-40176.

42. Bitan G, Tarus B, Vollers SS, Lashuel HA, Condron MM, Straub JE, Teplow DB: A molecular switch in amyloid assembly: Met35 and amyloid betaprotein oligomerization. J Am Chem Soc 2003, 125:15359-15365.

43. Cynis H, Scheel E, Saido TC, Schilling S, Demuth HU: Amyloidogenic processing of amyloid precursor protein: evidence of a pivotal role of glutaminyl cyclase in generation of pyroglutamate-modified amyloidbeta. Biochemistry 2008, 47:7405-7413.

44. Tekirian TL, Yang AY, Glabe C, Geddes JW: Toxicity of pyroglutaminated amyloid beta-peptides $3(\mathrm{pE})-40$ and -42 is similar to that of $A$ beta1-40 and -42. J Neurochem 1999, 73:1584-1589.

45. Harigaya Y, Saido TC, Eckman CB, Prada CM, Shoji M, Younkin SG: Amyloid beta protein starting pyroglutamate at position 3 is a major component of the amyloid deposits in the Alzheimer's disease brain. Biochem Biophys Res Commun 2000, 276:422-427.

46. Schieb H, Kratzin H, Jahn O, Mobius W, Rabe S, Staufenbiel M, Wiltfang J, Klafki HW: Beta-amyloid peptide variants in brains and cerebrospinal fluid from amyloid precursor protein (APP) transgenic mice: comparison with human Alzheimer amyloid. J Biol Chem 2011, 286:33747-33758.

47. Jawhar S, Wirths O, Bayer TA: Pyroglutamate amyloid-beta (Abeta): a hatchet man in Alzheimer disease. J Biol Chem 2011, 286:38825-38832.

48. Jawhar S, Wirths O, Schilling S, Graubner S, Demuth HU, Bayer TA: Overexpression of glutaminyl cyclase, the enzyme responsible for pyroglutamate A\{beta\} formation, induces behavioral deficits, and glutaminyl cyclase knock-out rescues the behavioral phenotype in 5XFAD mice. J Biol Chem 2011, 286:4454-4460.

49. Alexandru A, Jagla W, Graubner S, Becker A, Bauscher C, Kohlmann S, Sedlmeier R, Raber KA, Cynis H, Ronicke R, Reymann KG, Petrasch-Parwez E, Hartlage-Rubsamen M, Waniek A, Rossner S, Schilling S, Osmand AP, Demuth HU, von Horsten S: Selective hippocampal neurodegeneration in transgenic mice expressing small amounts of truncated Abeta is induced by pyroglutamate-Abeta formation. J Neurosci 2011, 31:12790-12801.

50. Wittnam JL, Portelius E, Zetterberg H, Gustavsson MK, Schilling S, Koch B, Demuth HU, Blennow K, Wirths O, Bayer TA: Pyroglutamate A(beta) aggravates behavioral deficits in 5XFAD mice. J Biol Chem 2012, 287:8154-8162.

51. Walsh DM, Klyubin I, Fadeeva JV, Cullen WK, Anwyl R, Wolfe MS, Rowan MJ, Selkoe DJ: Naturally secreted oligomers of amyloid beta protein potently inhibit hippocampal long-term potentiation in vivo. Nature 2002, 416:535-539.

52. Townsend M, Shankar GM, Mehta T, Walsh DM, Selkoe DJ: Effects of secreted oligomers of amyloid beta-protein on hippocampal synaptic plasticity: a potent role for trimers. J Physiol 2006, 572:477-492

53. Lesne S, Koh MT, Kotilinek L, Kayed R, Glabe CG, Yang A, Gallagher M, Ashe $\mathrm{KH}$ : A specific amyloid-beta protein assembly in the brain impairs memory. Nature 2006, 440:352-357.

54. Price DL, Tanzi RE, Borchelt DR, Sisodia SS: Alzheimer's disease: genetic studies and transgenic models. Annu Rev Genet 1998, 32:461-493.

55. Ashe KH, Zahs KR: Probing the biology of Alzheimer's disease in mice. Neuron 2010, 66:631-645. 
Moore et al. Alzheimer's Research \& Therapy 2012, 4:18

http://alzres.com/content/4/3/18

56. Bennett DA, Schneider JA, Arvanitakis Z, Kelly JF, Aggarwal NT, Shah RC,

Wilson RS: Neuropathology of older persons without cognitive

impairment from two community-based studies. Neurology 2006, 66:1837-1844.

57. Naslund J, Haroutunian V, Mohs R, Davis KL, Davies P, Greengard P, Buxbaum JD: Correlation between elevated levels of amyloid betapeptide in the brain and cognitive decline. JAMA 2000, 283:1571-1577.

doi:10.1186/alzrt121

Cite this article as: Moore et al.: Overlapping profiles of $A \beta$ peptides in the Alzheimer's disease and pathological aging brains. Alzheimer's

Research \& Therapy 2012 4:18. 